\title{
Pulmonary effects of exposure to fine fibreglass: irregular opacities and small airways obstruction
}

\author{
Kaye H Kilburn, Daniel Powers, Raphael H Warshaw
}

\begin{abstract}
Objective-Man made mineral fibres imitate asbestos and produce tumours of the pleura in animals. To answer the question, Does prolonged exposure to fibreglass adversely affect pulmonary function or produce radiographic abnormalities in human subjects? we studied workers in a midwestern applicance plant where refrigerator doors and previously entire cabinets were insulated with fibreglass sheeting and loose rotary spun fibreglass.

Methods-Spirometry and lung volumes were measured, respiratory and occupational questionnaires were administered, and chest $\boldsymbol{x}$-ray films were read for pneumoconiosis using International Labour Office (ILO) 1980 criteria in 284 workers with exposure of 20 years or more.
\end{abstract}

Results-Expiratory flows were reduced including $\mathrm{FEV}_{1}$ (mean $90.3 \%$ of predicted (pr), FEF $_{25-75}\left(85 \cdot 5 \%\right.$ pr), and FEF $_{75-85}(76 \cdot 2 \%$ pr). Forced vital capacity was significantly reduced (92.8\% pr) and total lung capacity was significantly increased (109.2\% pr). In white male smokers, a group large enough for comparisons, parameters of pulmonary function were reduced further in the presence of irregular opacities. Forty three workers $(15 \cdot 1 \%)$ had evidence of pneumoconiosis on chest radiographs: 26 of these (9.1\%), had no known exposure to asbestos and $17(6.0 \%)$ had some exposure. The best judgement was that in 36 $(13 \cdot 0 \%)$, pulmonary opacities or pleural abnormalities were due to fibreglass.

Conclusion-Commercial rotary spun fibreglass used for insulating appliances appears to produce human disease that is similar to asbestosis.

\footnotetext{
Environmental Sciences Laboratory, USC School of Medicine, 2025 Zonal Ave CSC 201, Los Angeles, CA 90033, USA and Workers Disease Detection Services, 441 West Allen Ave, Suite 114, San Dimas, CA 91773, USA

K H Kilburn, D Powers, R H Warshaw
}

Fibreglass and other man made mineral fibres have replaced asbestos for most insulating and construction functions in developed countries. Fibreglass may be a pulmonary toxin and carcinogen because it imitates asbestos, as do other man made mineral fibres. ${ }^{1}$ Their respirability and persistence in the lung probably determine their toxicity. ${ }^{2}$ Rotary spinning and flame attenuation of fibreglass produce heterogeneous diameters including some fibres less than $1 \mu \mathrm{m}$. Fibres smaller than $5 \mu \mathrm{m}$ in diameter have better insulating efficiency than larger ones ${ }^{2}$ but are respirable. Therefore we asked the question, Does prolonged exposure in an atmosphere containing fibreglass adversely affect pulmonary function or produce radiographic abnormalities? This question is difficult to answer because practically all construction and shipyard workers and most industrial workers exposed to fibreglass for 20 years, the minimal latent period for development of fibre disease if it is analogous to asbestosis, ${ }^{34}$ have been exposed to asbestos to some degree. Furthermore, man made fibres were manufactured in plants in which furnaces, retorts, ovens, and other facilities were insulated with asbestos. ${ }^{5}$ Repair, refitting, dismantling, and even construction of such facilities during manufacturing exposed the production workers to airborne asbestos even if they were bystanders of refurbishing operations. The only apparent solution to this dilemma is to study industrial users of fibreglass whose exposure to asbestos can be ascertained and compare those with exposure to fibreglass only with the dual exposure group. Such a population study should determine whether fibreglass imitates asbestos and causes small airways obstruction and air trapping and whether it produces irregular opacities in the lungs that can be seen on chest $x$ ray films. ${ }^{4}$ Therefore, workers exposed for 20 years or more to respirable burdens of rotary spun fibreglass insulation generated during its installation in refrigerators were examined.

Subjects and methods

From 1300 current and retired appliance manufacturing workers we invited the 500 workers with 20 years of exposure to fibreglass for examination. All were members of Local 571 of the Sheetmetal Workers' International Association who built 
refrigerators and stoves. Of the workers invited, 314 scheduled examinations and 284 men and women completed them. Work histories showed a pattern of many movements within the worksite of this plant for these employees of 20 years or more. Air sampling for fibres and total dust fit best with a shared air space exposure. Thus we concluded that retrospective reconstruction of exposures was not possible.

\section{EXPOSURE SITE AND JOB CATEGORY}

The plant was a four story building accommodating three levels of overhead conveyors. It was one large enclosure without interval walls except for the spray painting area, which was semi-enclosed. The calrod stove divison was in a separate building reached by enclosed walkways. Fibres could be seen in the air by their Tyndall effect in all work areas and they collected profusely on vertical and horizontal surfaces and especially on air duct screens. The only asbestos materials seen during a walk through the plant were around steam pipes. These were heavily painted and showed no evidence of having been disturbed.

\section{EXPOSURE MONITORING}

Twenty nine air samples were taken on 1 November 1989 with National Institute for Occupational Safety and Health personal samplers carried by assembly line workers for eight hours to characterise the workplace. When examined by light microscopy, they showed less than $0 \cdot 1-0.4$ fibres $/ \mathrm{ml}$ with total dust concentrations of $0.13-0.47 \mathrm{mg} / \mathrm{m}^{3}$ measured gravimetrically. Samples taken similarly in 1975 for fibreglass handlers showed respirable dust less than $0.1 \mathrm{mg} / \mathrm{m}^{3}$ and total dust concentrations of 2.5 to 4.2 $\mathrm{mg} / \mathrm{m}^{3}$. No asbestos fibres were reported in the samples by phase contrast microscopy. Diameters of 11 samples of fibreglass insulation used in refrigerator doors were measured by light microscopy. These samples showed heterogeneous fibreglass with diameters from 15 to less than $1 \mu \mathrm{m}$. Diameters from 3-7 $\mu \mathrm{m}$ predominated. Electron microscopic measurements of fibre size for five of the samples showed that $49 \%$ to $83 \%$ had diameters less than $5 \mu \mathrm{m}$ and $23 \%$ to $71 \%$ were less than $3.0 \mu \mathrm{m}$.

Lung tissue was analysed from one worker who died of congestive heart failure in 1989, before the study and after employment for 25 years in the refrigerator division. No chest $x$ ray films were found. The tissue contained peribronchiolar cellular infiltrates including fibroblasts around most terminal and respiratory bronchioles. Alveolar walls were thickened somewhat particularly in those alveoli adjoining bronchioles. In a pooled sample of 37 sites from the left lung there were 763 ferruginous bodies per $\mathbf{g}$ (dry weight). All had glass cores. A filter representing $2.62 \mathrm{mg}$ of the pooled lung sample was examined at 1600 times magnification with transmis- sion electron microscopy and contained 178000 fibres per dry lung. The morphology of all fibres was consistent with glass and this was supported by energy dispersive analysis that showed silicon, aluminium, and calcium but no magnesium or iron.

Workers were examined by chest radiograph, measurements of pulmonary function, questionnaires for occupational and medical histories, and physical examination of the chest. Chest $x$ ray films were repeated if necessary until posteroanterior films were satisfactory for evaluation of pneumoconiosis by International Labour Office (ILO) 1980 criteria. ${ }^{6}$ Lung areas were measured on posteroanterior and lateral views to compute total lung capacity (TLC). ${ }^{7}$ Films were interpreted for pneumoconiotic abnormalities (ILO criteria), irregular parenchymal opacities of profusion 1 (slight), 2 (moderate), and 3 (advanced or severe), and pleural abnormalities by comparison with standard films by two experienced readers. The 61 films on which their first readings differed were blinded and interpreted a second time by both readers after a six week interval. The 16 films on which there were differences on this reading were discussed in conference to reach a consensus interpretation.

Spirometry was done standing with a nose clip and using ATS Snowbird criteria ${ }^{8}$ except that expiration was continued to complete emptying or at least 10 seconds and repeated until two forced vital capacities (FVCs) agreed within $5 \%$. Forced expiratory volume in one second $\left(\mathrm{FEV}_{1}\right)$, mid-flows $\left(\mathrm{FEF}_{25-75}\right)$, and terminal flows $\left(\mathrm{FEF}_{75-85}\right)$ were measured and corrected to body temperature, prevailing atmospheric pressure, and water vapour saturation. In black men and women predicted values based on Caucasians were multiplied by 0.875 to adjust for ethnic difference before comparison with measured values. 9 The comparison population was a stratified random sample of a neighbouring state $\left(\right.$ Michigan $\left.^{10}\right)$. This sample had provided the regression equations to adjust $\mathrm{FEV}_{1}$, flows, and TLC for height, age, and duration of cigarette smoking. ${ }^{11}$ They resemble other United States populations studied but were used because other "standard" prediction formulae are based exclusively on never smokers and thus do not include coefficients for cigarette smoking (duration) or predictions for TLC. Results are expressed as group means of the per cent of predicted (pr) which were calculated for each person's tests. Although comparison of pulmonary function of a worker population with standard values derived from a general population sample may conceivably give an advantage to the workers, in practice this has not occurred. ${ }^{3412}$ Also, if workers' functions are decreased, as in this instance, any difference would be reduced.

The questionnaire was adapted from that of the respiratory standardisation project, ${ }^{13}$ with questions 
Table 1 Frequency of irregular opacities (0/0 to 2/1) and pleural abnormalities in all chest radiographs

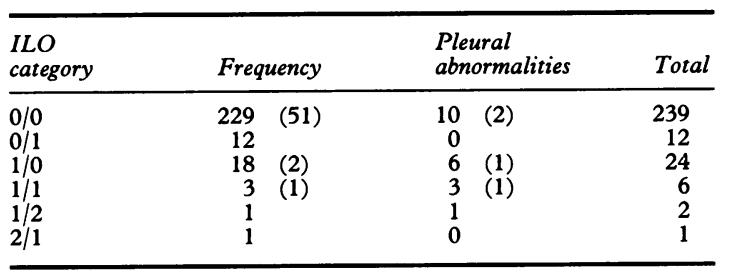

Workers exposed to asbestos in parentheses.

added to recognise asthma and heart disease. Exposure to asbestos, silica, fibreglass, solvents, and chemicals was inquired about with an additional pretested questionnaire. The physical examination of the chest recorded the quality of breath sounds and the presence of rales, wheezes, cyanosis, peripheral oedema, and digital clubbing. Never smokers had smoked less than 20 cigarettes.

\section{Results}

EXPOSURE DATA

Air samples examined by light microscopy showed relatively few fibres $(0 \cdot 1$ to 0.4 fibres $/ \mathrm{ml})$. Examination by electron microscopy showed that $49-83 \%$ of fibres in the fibreglass sheets were less than $5 \mu \mathrm{m}$ in diameter. We suspect these fine fibres became airborne and remained in the factory air for some time. Thus in the future, air samples should be examined by electron microscopy to determine which fibre sizes contribute to the dust concentrations of 0.13 to $0.47 \mathrm{mg} / \mathrm{m}^{3}$ in the manufacturing areas of this plant.

\section{CHEST RADIOGRAPHS}

Chest radiographs of 284 workers ( 182 men (91 black and 91 white) and 102 women (69 black and 33 white)) were examined for pneumoconiosis and 43 had abnormalities. Twenty nine men and four women had fine irregular opacities (ILO classification mostly $\mathrm{s} / \mathrm{s}$ but some with $\mathrm{s} / \mathrm{t}$ ) similar to those of asbestosis on chest $x$ ray films (table 1). Five of the 29 men had pleural as well as parenchymal abnormalities. Eight other men and two women had only pleural plaques or thickening on the chest wall or diaphragm. Of the 43 pulmonary and pleural signs, 17 reported some exposure to asbestos before or during appliance manufacturing. Twenty six identified no exposure to asbestos on repeated questioning. Of the 10 with only pleural abnormalities eight were exposed to fibreglass only and two were exposed to fibreglass and to asbestos. By comparison with most asbestos exposed cohorts, the irregular opacities were almost all fine (s/s) and distributed in the upper zones of the lung as well as in the lower and mid zones whereas profusions were relatively slight (1/0 to 2/1). None had signs of moderate or advanced asbestosis (profusion of opacities $2 / 2$ or greater).
From their questionnaires and interviews we regarded seven men as having had appreciable exposure to asbestos. This probably accounted for their chest radiographic findings. They included one man who had worked as a pipefitter for 15 years, one who had done home insulating with asbestos materials, two men with exposure to asbestos heat shields and three who had welded oven racks or calrod units for more than two years. Of the 43 workers with radiographic signs of pneumoconiosis, 18 were current smokers, 19 were ex-smokers, and six had never smoked cigarettes.

\section{CHRONIC BRONCHITIS AND ASTHMA}

The prevalence of chronic bronchitis (defined as cough and sputum for three months of each of two consecutive years) was $14.1 \%$ in never smokers, $10.8 \%$ in current smokers, and $7.6 \%$ in ex-smokers. Prevalence of asthma (defined as paroxysmal wheezing with or without shortness of breath that is relieved spontaneously or with medication) was $9.1 \%$ in never smokers, $5.4 \%$ in current smokers, and $3.3 \%$ in ex-smokers. These differences in prevalence of airway disease with smoking were different from expected and may reflect current and ex-smokers with seniority relocating into jobs with less exposure to fibreglass. Asthma and chronic bronchitis were somewhat more frequent in those whose $x$ ray films showed irregular opacities but the differences were not statistically significant. Eye irritation (in 18\%) and throat irritation (in 19.4\%) were common and chest burning, epistaxis, and haemoptysis were less prevalent mucous membrane complaints (table 2). There were no differences in symptom prevalences in workers with radiographic abnormalities as compared with those without them.

\section{SPIROMETRY AND LUNG VOLUMES}

Of 284 workers studied by chest $x$ ray films and questionnaires, 282 produced satisfactory physiological measurements. There were 31 white women and 91 white men (Caucasian and Hispanic), and 69 black women and 91 black men. After

Table 2 Prevalence of symptoms related to exposure to fibreglass and of asthma and chronic bronchitis

\begin{tabular}{|c|c|c|c|}
\hline & $\begin{array}{l}\text { All } \\
\text { workers }\end{array}$ & $\begin{array}{l}x \text {-Ray film } \\
\text { positive }\end{array}$ & $\begin{array}{l}x \text {-Ray film } \\
\text { negative }\end{array}$ \\
\hline $\begin{array}{l}\text { Number } \\
\text { Age (y) } \\
\text { Duration of fibreglass }\end{array}$ & $\begin{array}{l}284 \\
50 \cdot 5\end{array}$ & $\begin{array}{l}43 \\
54 \cdot 1\end{array}$ & $\begin{array}{l}241 \\
49 \cdot 8\end{array}$ \\
\hline exposure (y) & 19.9 & $23 \cdot 6$ & $19 \cdot 3$ \\
\hline Haemoptysis (\%) & $5 \cdot 6$ & $9 \cdot 3$ & $5 \cdot 0$ \\
\hline Nose bleed (\%) & $5 \cdot 6$ & $2 \cdot 3$ & $6 \cdot 2$ \\
\hline Nose irrigation (\%) & $13 \cdot 0$ & $11 \cdot 6$ & $13 \cdot 3$ \\
\hline Eye irritation $(\%)$ & $18 \cdot 0$ & 14.0 & $18 \cdot 7$ \\
\hline Throat irritation (\%) & $19 \cdot 4$ & 14.0 & $20 \cdot 3$ \\
\hline Chest burning (\%) & $10 \cdot 2$ & $11 \cdot 6$ & $10 \cdot 0$ \\
\hline Asthma (\%) & 6.0 & $8 \cdot 6$ & $5 \cdot 6$ \\
\hline Chronic bronchitis (\%) & 10.9 & $14 \cdot 0$ & $10 \cdot 3$ \\
\hline
\end{tabular}


Table 3 Comparison of pulmonary function as percentage of predicted between workers with pulmonary irregular opacities attributed to fibreglass exposure and workers without such opacities

\begin{tabular}{|c|c|c|c|c|c|}
\hline \multirow[b]{2}{*}{$\begin{array}{l}\text { Age (y) } \\
\text { FVC (\% pr) } \\
\mathrm{FEV}_{1}(\% \mathrm{pr}) \\
\mathrm{FEF}_{25-75}(\% \mathrm{pr}) \\
\mathrm{FEF}_{75-85}(\% \mathrm{pr}) \\
\mathrm{TLC}^{2}(\% \mathrm{pr}) \\
\mathrm{RV} / \mathrm{TLC} \\
\mathrm{FEV}_{1} / \mathrm{FVC}\end{array}$} & \multicolumn{2}{|c|}{$\begin{array}{l}\text { Workers with } \\
\text { opacities } \\
(n=27)\end{array}$} & \multicolumn{2}{|c|}{$\begin{array}{l}\text { Workers without } \\
\text { opacities } \\
(n=214)\end{array}$} & \multirow[b]{2}{*}{$\begin{array}{r}p \text { Valu } \\
<0.01 \\
<0.04 \\
<0.04 \\
0.20 \\
0.20 \\
<0.03 \\
<0.02 \\
<0.02\end{array}$} \\
\hline & $\begin{array}{r}54 \cdot 1 \\
87 \cdot 8 \\
82 \cdot 7 \\
75 \cdot 9 \\
68 \cdot 2 \\
113 \cdot 0 \\
51 \cdot 0 \\
70 \cdot 9\end{array}$ & $\begin{array}{l}(6 \cdot 4) \\
(11 \cdot 9) \\
(18 \cdot 6) \\
(37 \cdot 1) \\
(32 \cdot 0) \\
(11 \cdot 7) \\
(8 \cdot 6) \\
(12 \cdot 4)\end{array}$ & $\begin{array}{r}50 \cdot 1 \\
92 \cdot 9 \\
90 \cdot 8 \\
85 \cdot 8 \\
77 \cdot 3 \\
107 \cdot 7 \\
46 \cdot 6 \\
77 \cdot 1\end{array}$ & $\begin{array}{l}(7 \cdot 2) \\
(12 \cdot 6) \\
(14 \cdot 6) \\
(33 \cdot 5) \\
(43 \cdot 3) \\
(12 \cdot 1) \\
(8 \cdot 6) \\
(6 \cdot 8)\end{array}$ & \\
\hline
\end{tabular}

adjustment of all data for height, sex, age, duration of smoking, and ethnicity, ${ }^{6}$ we compared the 17 male workers with abnormal chest $x$ ray films who were current cigarette smokers with 39 male current smokers with normal chest $x$ ray films. The FVC was $85.9 v 96.0 \mathrm{pr}(\mathrm{p}<0.005)$ and $\mathrm{FEV}_{1}$ was $81.4 v 94.6$ pr $(\mathrm{p}<0.02)$. Both were significantly reduced. Thoracic gas volume and expiratory flow rates, also reduced in those with abnormal $x$ ray films, were not significantly different between these groups. When all 27 workers who showed abnormalities on radiographs attributed to fibreglass were compared with 214 workers without such abnormalities who were also without exposure to asbestos, they had significantly reduced $\mathrm{FEV}_{1}, \mathrm{FVC}$, and $\mathrm{FEV}_{1} / \mathrm{FVC}$ and significantly increased TLC and RV/TLC (table 3). Thus, the pattern of functional abnormalities in the entire group of 27 workers paralleled those in the 17 male current smokers. When all smoking groups were combined, TLC was increased. This is attributed to cigarette smoking, an important cofactor with fibreglass exposure in reducing pulmonary function.

The pulmonary function state of the entire exposed population separated by sex and ethnicity was compared (table 4). Because predictive equations for pulmonary function are the same for subjects of Hispanic origin and other Caucasians they are grouped as white. Pulmonary function was significantly reduced in both fibreglass only and fibreglass and asbestos exposed groups compared with a reference population. Of the 241 without abnormalities on $x$ ray film (ILO $0 / 0$ and $0 / 1$ ) 51 $(21.6 \%)$ reported some exposure to asbestos in the workplace. Separate comparison of this group for abnormalities of pulmonary function showed no significant differences from those reporting no exposure to asbestos. Comparisons of white women and of white men with their reference groups showed significant reductions in flows, $\mathrm{FEV}_{1}$, vital capacity, $\mathrm{FEV}_{1} / \mathrm{FVC}$, and increases in TLC and RV/TLC. The differences for black workers were similar and they were significantly below reference values also. Thus fibreglass workers exposed for 20 or more years had reduced pulmonary function.

Fibreglass was a major, but not the exclusive, air contaminant in this appliance manufacturing population. Some workers were also exposed to painting, metal cleaning and grinding, soldering, and vacuum forming of plastics that take place in the plant, and a few workers were exposed to metal welding in making heating elements for stoves. No associations were found between abnormality of pulmonary function and job site in the plant, that is nearness to packing of fibreglass into doors, soldering, or welding, or to the vacuum forming of plastics. As with asbestos exposed cohorts there was insufficient historic air sampling data to calculate or even to estimate cumulative fibreglass exposure for individual workers.

\section{Discussion}

EFFECTS OF AMOUNT OF WORKER PARTICIPATION

As only $63 \%$ of workers who met the criteria of 20 years of employment in this factory volunteered to be

Table 4 Comparison of pulmonary function in fibreglass exposed men and women with a reference population

\begin{tabular}{|c|c|c|c|c|}
\hline & $\begin{array}{l}\text { White women }(n=32) \\
\text { Mean }(S D)\end{array}$ & $\begin{array}{l}\text { Black women }(n=69) \\
\text { Mean }(S D)\end{array}$ & $\begin{array}{l}\text { White men }(n=91) \\
\text { Mean }(S D)\end{array}$ & $\begin{array}{l}\text { Black men }(n=91) \\
\text { Mean }(S D)\end{array}$ \\
\hline $\begin{array}{l}\text { Age (y) } \\
\text { Height (cm) } \\
\text { Weight (kg) } \\
\text { FVC (\% pr) } \\
\text { p Value } \\
\text { FEV }(\% \text { pr) } \\
\text { p Value } \\
\text { FEF }{ }_{25-75}(\% \text { pr) } \\
\text { p Value } \\
\text { FEF } \\
\text { p Value }(\% \text { pr) } \\
\text { TLC (\% pr) } \\
\text { p Value } \\
\text { RV/TLC } \\
\text { p Value } \\
\text { FEV } / \text { FVC }\end{array}$ & $\begin{array}{l}55 \cdot 1(7 \cdot 1) \\
157.9(6.0) \\
71.6(15 \cdot 6) \\
90 \cdot 8(15 \cdot 1) \\
<0.0283 \\
85.3(16 \cdot 6) \\
<0.0011 \\
68 \cdot 1 \quad(42 \cdot 8) \\
<0.0118 \\
58 \cdot 1 \quad(32 \cdot 4) \\
<0.0001 \\
108.9 \quad(14 \cdot 2) \\
<0.0014 \\
54.2 \quad(7 \cdot 7) \\
<0.001 \\
76.0 \quad(7 \cdot 4)\end{array}$ & $\begin{array}{l}48.6(7.0) \\
167.0(5.9) \\
83.9(15.0) \\
90.9(12.5) \\
<0.0011 \\
88.0(13.4) \\
<0.0001 \\
75.0(25.7) \\
<0.0017 \\
62.5 \quad(28.0) \\
<0.0001 \\
107.4 \quad(11.4) \\
<0.0010 \\
51.4 \quad(7.9) \\
<0.002 \\
77.6 \quad(6.3)\end{array}$ & $\begin{array}{ll}52.3 & (7.6) \\
170.3 \quad(6.7) \\
81.8 \quad(12.0) \\
94.4 \quad(12.0) \\
<0.0290 \\
91.9 \quad(16.2) \\
<0.0129 \\
91.4 \quad(36.5) \\
<0.2071 \\
84.7 \quad(41.4) \\
<0.0001 \\
107.3(10.7) \\
<0.0001 \\
44.4 \quad(8.8) \\
<0.001 \\
75.2 \quad(10.0)\end{array}$ & $\begin{array}{ll}48.5 & (6.0) \\
177.8 \quad(6.0) \\
87.9 \quad(15.0) \\
93.3 \quad(12.1) \\
<0.0290 \\
92.3 \quad(14.7) \\
<0.010 \\
93.6 \quad(32.2) \\
<0.02 \\
84.4 \quad(48.9) \\
<0.001 \\
112.4 \quad(12.7) \\
<0.0001 \\
43.5 \quad(6.2) \\
<0.001 \\
76.5 \quad(6.8)\end{array}$ \\
\hline
\end{tabular}

Results expressed as \% of predicted values. $\mathrm{p}$ Values (from comparisons with reference group) obtained by $t$ test. 
studied and $57 \%$ actually participated, we were concerned as to outcome bias by non-participants. Two possibilities exist. If workers with more severe pulmonary abnormalities stayed away the study would underestimate effects. If, on the other hand, those who considered themselves well and thought they were unaffected stayed away the study would be biased toward an overestimate. An objective of this preliminary study was to determine whether there were adverse health effects. As these were found and they were statistically significant, only the absence of workers without detectable disease would affect the conclusion. Considered most conservatively, if the 36 men and women with abnormalities on $x$ ray film (attributed to fibreglass) were the only positives in 500 eligible workers, the resulting prevalence of $7 \%$ would still be significantly above that in an unexposed population. ${ }^{14}$

\section{PULMONARY DYSFUNCTION}

The most important finding was reduction in mean values for flows including $\mathrm{FEV}_{1}$ and in FVC, with increased thoracic gas volume in workers exposed in this plant for 20 years compared with reference values from a general population sample. ${ }^{7111}$ If this comparison is accepted, then the remaining problem is whether the adverse effect on workers in this large multistory plant can be attributed to respirable fibreglass. The physiological impairment in this group of workers exposed to fibreglass consisted of airways obstruction (reduced $\mathrm{FEF}_{25-75}$ and $\mathrm{FEV}_{1}$ ) and air trapping (increased RV/TLC) with increased TLC. This same pattern was found in several thousand workers exposed to asbestos. ${ }^{34}$ Most of these workers, who also had low profusions of irregular opacities alone, pleural disease alone or both, had airways obstruction and air trapping with increased total lung capacities. The previous impression that asbestosis was a "restrictive disease" was based on TLC using the helium rebreathing or nitrogen washout methods, which fail to measure the "trapped" portion of the residual volume, ${ }^{15}$ thus underestimating TLC and RV because TLC$F V C=R V_{1}$. These signs of pulmonary dysfunction are more likely to result from fibreglass than from any of the multiple other exposures. Workers with exclusive exposure to fibreglass and mixed exposure to fibreglass and asbestos were not different for FEV and FVC but both had significant reductions in FEV and FVC compared with workers without radiographic abnormalities.

IRREGULAR OPACITIES ASSOCIATED WITH REFRIGERATOR MANUFACTURING

Exposure to cutting and packing sheets and loose rotary spun fibreglass, consisting of heterogeneous fibres with diameters from less than 1 to $15 \mu \mathrm{m}$, into refrigerator bodies and doors was associated with abnormalities on chest radiographs that are indistinguishable from asbestosis in $13 \%$ of workers exposed for 20 years or more. Exposure to fibreglass probably contributed to radiographic abnormalities in seven more workers who had histories of some exposure to asbestos. The only evident asbestos on a tour of the plant was painted asbestos cloth on steam pipes that probably covered magnesia-asbestos pipe insulation. Historically, there were asbestos pads on machines used to vacuum form plastic plates. We infer that at least part of the radiographic changes in these workers' lungs are due to fibreglass.

PREVALENCE OF IRREGULAR OPACITIES

These prevalences raise the issue of suitable comparisons. What are the prevalences of irregular opacities in populations not occupationally exposed to asbestosis? Two such populations of over 1000 each showed, for Michigan, a prevalence of $0.5 \%$ in men and $0.0 \%$ in women and for Long Beach, California, a shipbuilding city with an asbestos (transite) pipe plant, prevalence of $3.5 \%$ in men and $0.6 \%$ in women. $^{14}$ Clearly, the prevalences of irregular opacities found in this study are well in excess of such background values. Of other exposures in this appliance factory only asbestos characteristically produces irregular opacities in the lung. Man made fibres share pathogenic properties with asbestos and produce pleural mesothelioma and pleural fibrosis in animal chests. ${ }^{1617}$ Fibreglass also causes peribronchiolar fibrosis by inhalation. ${ }^{18}$ Titanium crystals and, rarely, other inhalants can cause pulmonary fibrosis. The absence of these rare exposures and the presence of fibreglass suggest that it is responsible for the radiographic abnormalities. Clearly the amount of exposure to asbestos in this factory, from our observations and by workers' histories was so low as to be below that of many indoor environments. ${ }^{19}$ Although previous exposure to asbestos as determined by workers' histories may be underestimated, most of these workers had no other industrial work experience. This leaves fibreglass as the only tenable cause.

\section{PREVIOUS STUDIES OF FIBREGLASS WORKERS}

These data, based on workers with 20 years or more of exposure, appear to fit on the upper edge of results from previous studies, which showed that 0 to $17 \%$ of workers had opacities in the lungs by radiography. No previous study effectively excluded exposure to asbestos so our maximal prevalence of $15 \cdot 1 \%$ might be the reasonable one for comparisons with those published. Wright, ${ }^{20}$ in 1968, reported "no abnormality" in 935 employees with 10 years of exposure in a glass fibre plant. Nasr et al $^{21}$ found that in 2028 male workers in glass fibre manufacturing of whom two thirds had been employed for 10 years or more, 26 had questionable to definite micronodular 
opacities for a prevalence of $1 \cdot 3 \%$. The prevalence would have been $1.9 \%$ if all of the opacities were in workers with 10 years or more of employment. When workers of 50 to 60 years of age were considered, however, $25.8 \%$ had abnormal radiographs and the prevalence rose to $52.4 \%$ in workers over 60 .

The first study to report use of ILO categories to characterise radiographs found small rounded opacities of profusion $0 / 1$ to $1 / 1$ in nine and irregular opacities of profusion $0 / 1$ to $1 / 1$ in 30 subjects for a rate of $17 \%$ overall. ${ }^{22}$ Studies of 1028 workers in seven factories with a mean duration of employment of 18 years, showed that 25 had small rounded opacities with a profusion of $1 / 0$ and six had a profusion of $1 / 1$. Such opacities were more common in smokers who had a prevalence of $3 \% .{ }^{23}$ In 340 workers manufacturing man made mineral fibres (275 for over 10 years), $11 \%$ had small rounded opacities of profusion $1 / 0$ or more. ${ }^{24}{ }^{25}$ The meaning of this characterisation as small rounded opacities is unclear. In arc welders such opacities were associated with alveolar infiltrates that cleared over several years after exposure ceased ${ }^{26}$ and may, in part, represent macrophage aggregates that have been noted in lungs of animals after exposure to welding fumes and gases. In silicosis the typical rounded opacities seen on radiographs are interpreted as periarteriolar and peribronchiolar collagenous nodules. Rounded opacities were not seen in the current study.

\section{FUTURE DIRECTIONS}

Careful studies of lungs from workers exposed to fibreglass are needed to assay the structural changes in the absence and presence of irregular (or round) opacities seen in radiographs. Such studies and the present ones will stimulate more research on human subjects to examine functional and structural (radiographic and histological) effects of fibreglass aside from cancer. Caution is advisable in interpreting results from a single study even considering the care taken to avoid asbestos, effects of which would lead to misattribution. A longitudinal study could be more convincing not only because workers would be their own controls but because dose could be measured and cumulative doses related to health effects. Closure of this plant shortly after this study obviated that option in these workers. It is viable in other groups and more cohorts should be studied. The major seemingly unsolvable problem is selection of groups for study because many potential ones have had coincident, and often simultaneous, exposure to asbestos as in insulators, and shipyard, and construction workers. It is likely that cutting and installing rotary spun fibreglass renders more respirable fibres airborne than does their production and packing. Further studies of fibre type and burdens in the lungs of workers who have used fibreglass should help to determine whether there are pathological changes in tissue corresponding to abnormalities in the chest $x$ ray films from fibreglass as there are from asbestos. Because fibreglass may be less fibrogenic and perhaps resides in the lung for shorter periods than asbestos, exposure may need to be continuous and of greater duration to produce effects equivalent to those of asbestos. If the presence of fibreglass disease is confirmed then reduction of human risk may necessitate manufacturing man made mineral fibres including fibreglass at diameters above the respirable range for the human lung. By contrast with asbestos, fibreglass diameters are potentially controllable during manufacture.

The men and women of the Sheet Metal Workers' International Association Local Union 571 and their president and business agent, John Agrela made this study possible. A contract with the Sheet Metal Occupational Health Institute Inc, Washington, DC provided financial support. Quantification and size characterisation of fibreglass by electron microscopy was done by Glenn Williams and Dr Ronald Dodson, of the University of Texas, at Tyler, Texas.

1 Lockey J, Moatamed F. In: JB Gee, ed. Health implications of non-asbestos fibers in occupational lung disease. New York: Churchill Livingstone 1984:75-98.

2 International agency for Research on Cancer. Monographs on the evaluation of carcinogenic risks for humans. Vol 43. Man made mineral fibres and radon. Lyon: WHO, IARC, 1988.

3 Kilburn KH, Warshaw RH. Pulmonary functional impairment associated with pleural asbestos disease. Chest 1990;98: 965-72.

4 Kilburn $\mathrm{KH}$, Warshaw RH. Abnormal lung function associated with asbestos disease of the pleura, the lung, and both: a comparative analysis. Thorax 1991;46:33-8.

5 Kilburn KH, Warshaw RH. Difficulties of attribution of effect in workers exposed to asbestos and rotary spun fiberglass. $\mathrm{Am} \mathrm{J}$ Ind Med 1991;20:745-51.

6 International Labour Office. Guidelines for the use of ILO international classification of radiographs for pneumoconiosis. Geneva: ILO, 1980. (Occupational safety and health series No 22.)

7 Harris TR, Pratt PC, Kilburn KH. Total lung capacity measured by roentgenograms. Am J Med 1971;50:756-63.

8 ATS Statement: Snowbird workshop on standardization of spirometry. Am Rev Respir Dis 1979;119:831-8.

9 Rossiter $\mathrm{CE}$, Weill $\mathrm{H}$. Ethnic differences in lung function: Evidence for proportional differences. Int J Epidemiol 1974;3:55-61.

10 Miller A, Thornton JC, Warshaw R, Bernstein J, Selikoff IJ, Teirstein AS. Mean and instantaneous expiratory flows, FVC, and $\mathrm{FEV}_{1}$ : Prediction equations from a probability sample of Michigan, a large industrial state. Bull Eur Physiopathol Resp 1986;22:589-97.

11 Kilburn KH, Miller A, Thornton JC, Warshaw RH. Predictive equations for total lung capacity and residual volume from radiographs based on a probability sample of the Michigan population. Thorax 1992 (in press).

12 Kilburn KH, Warshaw R, Thornton JC. Pulmonary function in histology technicians compared with women from Michigan: effects of chronic low dose formaldehyde on a national sample of women. Br J Ind Med 1989;46:468-72.

13 Ferris BJ Jr. Epidemiology standardization project. Am Rev Respir Dis 1978;118:7-54.

14 Kilburn KH, Lilis R, Anderson HA, Miller A, Warshaw RH. Interaction of asbestos, age and cigarette smoking in producing radiographic evidence of diffuse pulmonary fibrosis. $\mathrm{Am} \mathrm{J}$ Med 1986;80:377-81.

15 Kilburn KH, Miller A, Warshaw RH. Measuring lung volumes in advanced asbestosis: Comparability of plethysmographic 
and radiographic versus helium rebreathing and single breath methods. Resp Med 1992 (in press).

16 Stanton MF, Wrench C. Mechanisms of mesothelioma induction with asbestos and fibrous glass. J Natl Cancer Inst 1972;48:797-821.

17 Lee KP, Barras CE, Griffith FD, Waritz RS. Pulmonary response to glass fiber by inhalation exposure. Lab Invest 1979;40:123-33.

18 Botham SK, Holt PF. Comparison of effects of glass fibre and glass powder on guinea pig lungs. $B r J$ Ind Med 1973;30: $232-6$.

19 National Research Council. Asbestiform fibers: Nonoccupational health risks. Washington DC: National Academy Press, 1981:71-6.

20 Wright GW. Airborne fibrous glass particles. Chest roentgenograms of persons with prolonged exposure. Arch Environ Health 1968;16:175-81.

21 Nasr ANM, Ditchek T, Scholtens PA. The prevalence of radiographic abnormalities in the chests of fiber glass workers. J Occup Med 1971;13:371-6.
22 Valentin H, Bost H-P, Essing H-G. Are glass fibre dusts of concern for health. Berufsgenossenschaft 1977; February, 60-64. (In German.)

23 Weill H, Hughes JM, Hammad YY, Glindmeyer HW III, Sharon G, Jones RN. Respiratory health in workers exposed to man-made vitreous fibers. Am Rev Respir Dis 1983;128:104-12.

24 Hill JW, Whitehead WS, Cameron JD, Hedgecock GA. Glass fibres: absence of pulmonary hazard in production workers. $\mathrm{Br}$ $J$ Ind Med 1973;30:174-9.

25 Hill JW, Rossiter CE, Foden DW. A pilot respiratory morbidity study of workers in a MMMF plant in the United Kingdom. In: Biological effects of man-made mineral fibres (proceedings of a WHO/IARC conference). Vol 1. Copenhagen: World Health Organisation 1984:413-26.

26 Doig AT, McLaughlin AIG. Clearing of $x$-ray shadows in welder's siderosis. Lancet 1948;i:789-91.

Accepted 20 January 1992 